\title{
Biologicals and biosimilars: safety issues in Europe
}

\author{
Maria da Conceição Constantino Portela, Carlos Sinogas , Fernando \\ Albuquerque de Almeida, Ricardo Baptista-Leite \& Alexandre Castro-Caldas
}

To cite this article: Maria da Conceição Constantino Portela, Carlos Sinogas , Fernando Albuquerque de Almeida, Ricardo Baptista-Leite \& Alexandre Castro-Caldas (2017): Biologicals and biosimilars: safety issues in Europe, Expert Opinion on Biological Therapy, DOI: 10.1080/14712598.2017.1330409

To link to this article: http://dx.doi.org/10.1080/14712598.2017.1330409

曲 Published online: 25 May 2017.

Submit your article to this journal $\widetilde{ }$

凹 Article views: 25

Q View related articles $\sqsubset$

View Crossmark data 


\title{
Biologicals and biosimilars: safety issues in Europe
}

\author{
Maria da Conceição Constantino Portela $\mathbb{1}^{\mathrm{a}}$, Carlos Sinogas $\mathbb{1}^{\mathrm{b}, \mathrm{c}}$, Fernando Albuquerque de Almeida , \\ Ricardo Baptista-Leite (10) ${ }^{\mathrm{a}, \mathrm{e}}$ and Alexandre Castro-Caldas (1) ${ }^{\mathrm{a}}$ \\ aInstituto de Ciências da Saúde, Universidade Católica Portuguesa, Lisboa, Portugal; bACF - Acompanhamento Farmacoterapêutico, Lda Pavia, \\ Portugal; 'Departamento de Biologia, Escola de Ciências e Tecnologia, Universidade de Évora, Évora, Portugal; 'Institute of Health Policy \& \\ Management, Erasmus University Rotterdam, Rotterdam, The Netherlands; eFaculty of Health, Medicine and Life Sciences, Maastricht University, \\ Maastricht, The Netherlands
}

\section{ABSTRACT}

Introduction: Medicinal products of a biological origin are approved by the EMA at a centralized level. However, there is no harmonization about their use in Europe. The current regulation referring to the safety of biological medicinal products and biosimilars in Europe has been identified. The safety associated with medicinal products of a biological origin is assured by the pharmacovigilance system, which has evolved, but doesn't yet incorporate all of the specific information from this market segment, namely that related to the identification of drugs, and its use - including the prescription and dispensing, given the possibility of interchangeability and substitution. The terminology, information systems and traceability systems aren't entirely appropriate to ensure the safety requirements for therapy with medicinal products of a biological origin.

Areas covered: This article aims to identify the prescription and dispensing profiles of reference biological medicines and biosimilars in the EU, and the determinants that support their safe use.

Expert opinion: The European pharmacovigilance system must evolve to ensure the safety along all of the biologicals' therapeutic cycle. It must consider the safety for each of the medicines in addition to their safety pattern related to the eventual switching procedure.
ARTICLE HISTORY

Received 21 February 2017 Accepted 10 May 2017

\section{KEYWORDS}

Biologicals; biosimilars; pharmacovigilance; safety; substitution; interchangeability

\section{Introduction}

The approval of biologicals by a centralized procedure is followed by additional safety monitoring [1], and their utilization is usually based on national regulations. The safe use of biologicals in the European Union (EU) can be improved by efficient coordination between European and national regulations.

Because the manufacturing of reference biologicals and biosimilars is based on cells and living organisms, their variability depends upon manufacturer-specific conditions, which can impact their efficacy and safety [2,3]. The practice of interchangeability between reference biologicals and biosimilars can sustain increasing pharmaceutical expenditures $[4,5]$.

To continuously ensure safety, the pharmacovigilance system must follow updated technical and scientific knowledge [6]. Additionally, clinical practice related to biosimilars can impose new legislation, due to the nonspecificity of current one $[7,8]$.

The European Medicines Agency (EMA) was the first institution in the world to establish regulatory guidelines for safety assessments of biological medicinal products during the premarketing authorization phase. Additionally, EMA also established guidelines for biosimilars, which led to the approval of the first biosimilar in 2006 [9-12] (Table 1). The approval of the first biological product occurred in 1980. However, EMA and WHO consider that during the marketing phase, prescribing guidelines should be issued by the authorities of each Member State. It was only in 2009 that the Food and Drug Association (FDA) recognized biosimilar status with the publication of the Biologics Price Competition and Innovation Act. Later, by 2017, the publication of 'Considerations in demonstrating interchangeability with a reference product - Guidance for industry' provided new guidance related to switching studies for drugs intended to be administered more than once [13]. The FDA also classified drugs covered by interchangeability $[14,15]$. In the EU, each Member State defines the requirements for interchangeability and substitution. In international settings, the terminology of biosimilars is diverse (Table 2) [16-20].

The safety of biologicals requires traceability of the patient as well as of the drug's basic components and raw materials. Regulation 1394/2007 of 13 November covers the drug's entire life cycle, from the source of the recombinant cell and raw materials until its final use by the patient. A decision concerning the drug's safety is made according to the severity of adverse reactions (Table 3) [21].

Reports of suspected adverse reactions are required from the marketing authorization (MA) holder, health-care professionals, and patients. The Eudravigilance database centralizes data and allows effective safety coordination in the EU. This monitoring unfolds through the activities of 'detection, assessment, minimization and communication relating to the risk of adverse reactions, while taking the therapeutic effect of the medicine for human use 
Article highlights

- Biologicals and biossimilars have centralized approval by EMA

- Switching (interchangeability and substitution) is regulated by Member States

- Safety assessment of biologicals relies on pharmacovigilance data both pre-and post marketing

- The pharmacovigilance system oversees each drug's benefit-risk assessment

- Potential risks related to switching are not adequately assessed in Europe due to the absence of specific safety tools

This box summarizes key points contained in the article.

Table 1. Regulatory framework for biosimilars approval by EMA and FDA [10-13].

\begin{tabular}{|c|c|}
\hline EMA (Europe) & FDA (United States) \\
\hline $\begin{array}{l}\text { Biosimilars approval: Based on } \\
\text { demonstration of the similarity in } \\
\text { terms of quality, biological activity, } \\
\text { safety, and efficacy } \\
\text { Interchangeable approval: Not } \\
\text { applicable }\end{array}$ & $\begin{array}{l}\text { Biosimilars approval: Based on the } \\
\text { demonstration of similarity in terms } \\
\text { of safety, purity, and potency } \\
\text { Interchangeable approval: Based on } \\
\text { the demonstration of similarity, and } \\
\text { data or information about provision } \\
\text { of the same clinical result as the } \\
\text { reference druq }\end{array}$ \\
\hline $\begin{array}{l}\text { Evidence generated by similarity } \\
\text { based on comparability studies } \\
\text { Intends to provide the basis for the } \\
\text { approval based on a reference } \\
\text { product }\end{array}$ & $\begin{array}{l}\text { Evidence generated by similarity or } \\
\text { interchangeability studies } \\
\text { Intends to provide the basis for the } \\
\text { approval based on a reference } \\
\text { product }\end{array}$ \\
\hline $\begin{array}{l}\text { Evaluation of biosimilars does not } \\
\text { consider interchangeability neither } \\
\text { substitution considerations }\end{array}$ & $\begin{array}{l}\text { Evaluation allows for the approval of } \\
\text { biosimilars and for interchangeable } \\
\text { drugs (i.e. drugs that may } \\
\text { substitute reference drugs without } \\
\text { the intervention of the prescriber of } \\
\text { reference product) }\end{array}$ \\
\hline
\end{tabular}

into account, and the responsibility for the design and evaluation of post-authorization safety studies and pharmacovigilance audits' [22]. The Pharmacovigilance Risk Assessment Committee (PRAC) aims to foster peer-to-peer communication and the taking of joint positions. PRAC, along with the Coordination Group of Pharmacovigilance Activities, provides information to the Committee for Medicinal Products for Human Use.

Specific regulations allow continuous monitoring of the benefit-risk ratio of the drug, the functioning of the risk management system, monitoring of the results and measures undertaken for risk minimization, collection and evaluation activities and communication of safety reports related to individual cases, procedures for preparation and submission of periodic safety reports, and procedures for communication with health-care professionals and the public at the time of risk identification; risk identification requires the adoption of measures affecting the use of medicines [23].

Risk management plans are usually required for biosimilars $[18,22]$. Post-authorization safety studies can be included to allow for real-world use data, which can support the withdrawal of MA (Table 4) [24,25].

Because there is segmentation of risk among drugs, an additional monitoring system was needed to cover medicinal products containing a new active substance, biological medicinal products and biosimilars, and products requiring postauthorization data. To enable the prompt identification of medicinal products subjected to additional monitoring either by patients or health-care professionals - the use of a black inverted equilateral triangle on the product's packaging was recommended [22].

Additionally, the use of a unique standardized identifier is considered an adequate procedure for coping with risk management [26]. These identifiers can ensure the identification, localization, and authentication of medicinal products in Europe. This system will be in force from February 2019.

Specific safety concerns related to crossborder health care and traceability require the implementation of regulations related to medical prescriptions, which must address the trade name, dosage form, quantity, dose, and dosage [27].

\section{Interchangeability and substitution in European countries}

The criteria for the prescribing of medicines are based in each of the Member States, as prescriptions are one of the most important pathways for accessing the generic market [28]. Additionally, interchangeability and substitution are regulated for biosimilars and can be considered for different MA holders. The definition of biosimilars, and following patterns of switching, will impact on market share because prescription by International Non-

Table 2. Worldwide designation of biological and biosimilar drugs [16-20].

\begin{tabular}{|c|c|c|}
\hline Designation & Country & Characteristics \\
\hline Biosimilar products & EU & Biosimilars \\
\hline FOPs & United States of & Biosimilars \\
\hline FoBs & America (USA) & \\
\hline SEB & Canada & Biosimilars \\
\hline SBMPS & WHO & Biosimilars \\
\hline RBP & & Reference drug \\
\hline Precedent biotechnology drug & Japan & Biosimilars \\
\hline Biopharmaceuticals & NA & Drug products that contain biotechnology derived proteins as active pharmaceutical ingredients \\
\hline $\begin{array}{l}\text { Biopharmaceutical products not subject to } \\
\text { regulatory approval (B-NSRA) }\end{array}$ & NA & \\
\hline Bioidenticals & NA & $\begin{array}{l}\text { Same product ('same vessel' in terms of active pharmaceutical ingredient, device might be } \\
\text { different) sold under different brand names by different companies }\end{array}$ \\
\hline Biobetters or biosuperiors & NA & $\begin{array}{l}\text { Drugs that are similar to innovator biologics but are characterized by some change in the } \\
\text { structure of the protein or the process by which they are made, with the goal of improved } \\
\text { efficacy, safety, or immunogenicity }\end{array}$ \\
\hline Superbiosimilars & NA & $\begin{array}{l}\text { Second generation versions of biosimilars, the development of which will drive the longer term } \\
\text { market growth }\end{array}$ \\
\hline
\end{tabular}

FOPs: Follow-on protein products; FoBs: follow-on biologics; SEB: subsequent-entry generics; SBMPs: similar biotherapeutic products; RBP: reference biotherapeutic product. 
Table 3. Adverse reaction, serious adverse reaction, and unexpected adverse reaction definition.

\begin{tabular}{|c|c|}
\hline Name & Definition \\
\hline Adverse reaction & $\begin{array}{l}\text { Refers to 'A response to a medicinal product which is } \\
\text { noxious and unintended and which occurs at doses } \\
\text { normally used in man for the prophylaxis, diagnosis } \\
\text { or therapy of disease or for the restoration, correction } \\
\text { or modification of physiological function' [6]. } \\
\text { When the adverse reaction results from 'medication } \\
\text { errors, use outside the terms of MA, including misuse } \\
\text { and abuse' [21] }\end{array}$ \\
\hline $\begin{array}{l}\text { Serious adverse } \\
\quad \text { reaction }\end{array}$ & When results in death or is life-threatening \\
\hline $\begin{array}{l}\text { Unexpected } \\
\text { adverse reaction }\end{array}$ & $\begin{array}{l}\text { When there is not consistency with Summary of Product } \\
\text { Caractheristics (SmPC) information }\end{array}$ \\
\hline
\end{tabular}

Table 4. Drug and market interventions following adverse reactions [24].

\begin{tabular}{ll}
\hline Severity of adverse reaction & \multicolumn{1}{c}{ Intervention } \\
\hline Minor & Inclusion of a new contraindication \\
& Dose reduction \\
& Restriction of therapeutic indications \\
Major & MA suspension or revocation \\
& Drug delivery interdiction \\
& MA renewal rejection \\
\hline
\end{tabular}

Proprietary Name (INN) has been mandatory in some European countries since 2004 (specifically, in Spain, France, Italy, Ireland, the United Kingdom, Estonia, and Malta) [29]. This legislation enables interchangeability, allowing the original or a biosimilar drug to be dispensed without distinction [30]. However, there are problems that should be prevented, such as unintentional substitution as well as the practice of interchangeability, which must be based on scientific evidence [31].

Interchangeability and substitution should be based on regulations and should be able to add clarity to clinical practice [32]. Usually, interchangeability is not recommended if the patient is stable from a clinical point of view [33]. However, this issue is only relevant if the efficacy and safety patterns of biosimilars have a clinical impact [34]. In such cases, drugs are not interchangeable [35].

Substitution has different requirements in different states; these differences are misleading and require careful assessment. Substitution can be related to the practice of prescribing by INN, to the substitution by a biosimilar when dispensing at pharmacies, and to interchangeability among biosimilars or between original biologicals and biosimilars. Nonetheless, there is a broad concept that relates interchangeability to the practice of prescribing and relates substitution to the practice of dispensing.

Regulations in France, Germany, and Spain do not allow the automatic substitution of biologicals, by 2011 [36]. Because they are different medicines, substitution between biosimilars should not occur [37].

The literature reports that exact replication and consistent manufacturing of biologicals is a challenge, and guidelines allow the evaluation of biosimilars [38]. Comparability and similarity are central topics: the first aims to confirm physical-chemical and biological specifications between different batches of the same product, while the second intends to ensure similarity between the biosimilar and the reference product [39].

According to EMA, the authorization of interchangeability and substitution is a responsibility of the states. In contrast, the FDA classifies interchangeable biosimilars as well as those that are new active substances for which interchangeability with the reference medicinal product is not allowed [40]. Different regulations support both.

In Europe, interchangeability between the reference medicinal product and biosimilars is generally accepted, contrary to what occurs with substitution. In fact, due to the traceability of adverse reactions associated with the reference product, substitution by biosimilars should not be immediate [41]. Most European states do not allow automatic substitution, having excluded biosimilars from their lists of medicines for substitution [42]. By the contrary, interchangeability is entering into force.

For the European Generics Association, interchangeability 'refers to the medicinal/pharmaceutical practice of switching one medicine for another that is equivalent, in a clinical setting. A product is considered interchangeable if it can be administered or dispensed instead of another clinically approved product' whereas 'substitution refers to the practice of dispensing ... at pharmacy level and without consultation of the prescriber' [31]. The WHO defines interchangeability as 'the medical practice of switching one medicine for another that is equivalent, in each clinical setting' and adds that 'the decision to allow automatic substitution of a similar biotherapeutic product for a reference biotherapeutic product should be made on a national level taking into account potential safety issues with the product or class of products' [31].

Usually, automatic substitution by biosimilars is not allowed. However, this pattern has been changing [43]. There are various approaches, including MA using the same original product, the same manufacturer, or the same manufacturing process [44]. Considering current evidence, some authors see no risks in interchangeability [45].

Belgium does not allow either interchangeability or substitution of the prescribed medicine [41]. In Denmark, interchangeability and substitution occur under the terms of MA approval, which requires the demonstration of similarity. It is assumed that there are no differences in the medicines' safety or efficacy profiles [46].

In Spain, biological medicinal products are not covered by the principles of interchangeability and substitution $[47,48]$. In 2006, published legislation required the systematic use of the INN for prescription purposes; in 2013, it was decided that the brand name should be employed preferentially [49].

Based on official information, interchangeability and substitution are accepted in Finland if there are no increased adverse effects associated with any of these procedures [50,51]. Substitution takes place only among drugs that are part of a list published quarterly by the MA [41]. The registry of information associated with interchangeability and substitution, namely the brand name and batch number, should be assured [47].

In France, the framework for the utilization of biologicals has evolved since 2007, when the unique identity of these drugs was first recognized and the differences between biosimilars and the original medicines were made clear; automatic substitution was prohibited until 2014 [52]. However, France was the first country to allow substitution in pharmacies, but only at the beginning of treatment [39]. However, the medicines must be in the same biologic group, and the prescriber 
Table 5. European pattern related with interchangeability and automatic substitution.

\begin{tabular}{lll}
\hline Country & \multicolumn{1}{c}{ Interchangeability } & Automatic substitution \\
\hline Belgium & Allowed & Allowed \\
Denmark & Allowed & Allowed \\
Finland & Allowed & Allowed \\
France & Allowed with restrictions & Allowed with restrictions \\
Germany & Allowed with restrictions & Allowed with restrictions \\
Italy & Allowed with restrictions & Not allowed \\
Netherland & Allowed with restrictions & Not allowed \\
Portugal & Allowed with restrictions & Not allowed \\
Spain & Not allowed & Not allowed \\
Sweden & Not allowed & Not allowed \\
United Kingdom & Strictly allowed & Not allowed \\
\hline
\end{tabular}

must agree with the substitution $[39,41]$. Once the treatment is ongoing, substitution is not allowed in any case [41]. In the Netherlands, interchangeability is allowed only under specific conditions that ensure safety [53,54]. In Italy, automatic substitution is not allowed [40].

In Portugal, the Centros Prescritores de Agentes Biológicos (Centres for Biologicals Prescription) - registered in 'Direção Geral da Saúde' - ensure monitoring activities [55]. INFARMED (the Portuguese Medicines Authority), through the 'Comissão Nacional de Farmácia e Terapêutica' (National Pharmacy and Therapeutics Committee), published a document that guides the prescription of biologicals; interchangeability is considered in specific situations, but substitution is not [56].

In the United Kingdom, brand-name drugs are preferred. Moreover, hospitals are encouraged to disclose favorable results achieved using biosimilars [40]. Substitutions must only take place when accompanied by a reasoned decision made by the prescriber [41]. In Sweden, there is an official list of drugs that may be subject to substitution, but biosimilars are not included on that list due to their complexity [41]. The utilization criteria for biological medicinal products in the EU are summarized in Table 5.

\section{The terminology of biologicals}

The management of the information that contributes to safety reports relies on a general nomenclature. While original drugs are well characterized by their brand names, biosimilars rely on the INN. The WHO proposes that the MA holder and batch number must also be considered. In fact, if there is no accurate terminology to differentiate among biosimilars, there will be confusion regarding naming when trying to establish causality related to adverse events. Additionally, the nomenclature should be the same in all countries to allow traceability $[29,57]$. Currently, INN allocation requests for biological medicinal products account for $40 \%$ of all submissions to the WHO [58].

To overcome the limitations of the current system and ensure accurate identification of biologicals, the WHO established the system of biological qualifiers, which 'is a random alphabetic code assigned to a biological active substance on application by a biological qualifier (BQ) applicant and used in medicines distributed by a Marketing Authorisation Holder.' The allocation must occur in both directions, both prospectively and retrospectively [57]. Biological qualifiers consist of four randomized consonants, used after the brand name or
INN. The biological qualifier will be used if the same amino acid sequence and the same INN are maintained. The use of biological qualifiers must ensure the identification of biological substances related to prescribing and dispensing; this practice is intended to facilitate pharmacovigilance and to support the transfer of medication prescriptions [57].

\section{Risk and traceability}

Due to the controlled conditions of clinical trials, the safety and efficacy profiles of a drug are incomplete at the time of MA [59]. Pharmacovigilance enables the identification and definition of the risks related to the use of drugs in real-world conditions [41]. This information can support the conditions of interchangeability and substitution, as well as their background methodologies [32]. However, clinical trials that are capable of specifically evaluating switching-related risks are still currently lacking in Europe. It was found that 3 years after their marketing approval, 14\% of medicines are subject to interventions, a figure that increases to $29 \%$ after 10 years [57]. Moreover, the first medicines belonging to a new therapeutic class are associated with an increased prevalence of adverse events [60].

Biologicals carry the potential risk of immunogenicity $[61,62]$. However, there are also risks of autoimmunity and potential diversity of efficacy, mainly for biosimilars [19]. According to other authors, the safety profile of biologicals indicates that most of their adverse effects are due to their biological activity and not to an immunologic response such as hypersensitivity. The risk can also be modified by the presence of contaminants [28]. However, risks are also related to the drug's exposure, route of administration, therapeutic indication, and severity of the disease [19].

A specific classification for the reporting of adverse reactions associated with biologicals has been developed [63]. When side effects do not show a temporal coincidence with the use of medicines, it is normal to find a reduced number of notifications of suspected adverse reactions. In such a case, the role of pharmacists is essential and relevant, as society depends on them to ensure the traceability of biologicals [28]. The traceability of biologicals can be ensured through an integrated individual record of prescriptions or through the enrolment of patients in an observatory for monitoring. The literature also proposes establishing a serologic library with registries of the development of antibodies associated with the administration of drugs of different brands [64].

\section{Conclusion}

The European MA of biologicals is centralized by the EMA. However, this institution does not comment on the criteria for the use of these products. Rather, it allows each Member State to rule on this topic.

Biosimilar drugs are approved after the patent on the original product expires. Although they do have the same active ingredient, dose, and pharmaceutical formulation, biosimilar drugs are not equivalent to the original drug in the same way that generics are identical to the reference drug, but they are similar. This fact stems from the nature and complexity of biologicals, whose manufacturing process explains the variability among different batches of the same drug and among medicines obtained from 
different manufacturers or MA holders. A systematic review of the literature notes the theoretical possibility of the occurrence of changes in the efficacy and safety profiles between the original biologicals and biosimilars. However, robust data from scientific evidence is still lacking.

Based on these facts, the positions of Member States regarding the preferential option for original biologicals or biosimilars are not uniform. Although European centralized approval allows the marketing of these products simultaneously among Member States, there is no consistency among the dates of effective marketing, nor about entry into force of the positions assumed, neither is there uniformity across selected regulatory instruments. An evolution in the positions assumed by some countries has also been observed, from very conservative and constrained postures toward the use of these drugs to more diversified positions toward the selection of original biological or biosimilar drugs. This development has been accompanied by the implementation of additional measures to reinforce monitoring, to provide information to health-care professionals, and to establish procedures, collection systems, and information analyses to strengthen future decision criteria based on scientific evidence.

The regulatory interventions that have been considered came from two fundamental perspectives: therapeutic and economic. The first is always observed and is based on the terms of interchangeability and substitution patterns that must be followed to guarantee the safety and efficacy of biological therapy, while the second is only observed for some of the states and is based on financing typologies of biologicals and related incentives.

For most states, the positions assumed in the areas previously identified were formalized through guidance documents issued by the Medicines Authorities, which can be updated as scientific evidence becomes available.

Regardless of the regulatory tools that are used, the key factor affecting the choice between original biologicals and biosimilars - whether based on interchangeability or substitution - is always patient safety. Due to this, healthcare professionals should be able to access registries related to previous data about patients' biological therapies.

Therapy with reference drugs should be the rule in complex and severe cases, once the patient is stabilized. If the practice of interchangeability can be accepted in duly identified specific situations, substitution must be discouraged in dispensing medications of biological origin.

Opting for interchangeability and substitution practices requires the establishment of monitoring and surveillance systems appropriate to the nature of the therapy. The creation of robust scientific evidence is also required. For this purpose, the adoption of terminology and of analytical criteria appropriate to the characterization of specific adverse effects of biological medicinal products must be considered. Also worth considering is the creation of a track record of the use of drugs of biological origin in all Member States, as is already in place in some of them, as this record would enable the systematization and monitoring of information.

When evaluating suspected adverse drug reactions to biologicals, namely adverse events related to the immune system (potential immunogenicity, adventitious infection, or autoimmunity), the patient's characteristics must be considered. The patient's comprehensive records pertaining to biologicals, including the identification of the manufacturer and batch number in addition to the active substance, should allow for personalized therapeutic decisions. These clinical files should also support pharmacovigilance of biologicals.

In addition, a common and more specific terminology must be in force because the INN system is far from adequate for documenting the adverse events associated with biologicals. By extension, an update on the reporting criteria for adverse reactions related to the interchangeability and substitution of biologicals should be in force.

A biological's safety pattern should rely on both retrospective and prospective information related to adverse reactions reports; there should be registration of continuous prescription data related with the therapeutic cycle, including the frequency of interchangeability and substitution. The identification of patients at potential risk should be regulated.

\section{Expert opinion}

Biologicals and biosimilars are highly complex molecules that need to prove similarity based on comparability studies to gain $M A$; similarity must be based on the chosen reference biological product. However, unlike routine use, clinical trials do not currently address interchangeability and substitution. There is a gap related to risk assessment based on switching. The EMA does not provide opinions about interchangeability and substitution practices because these practices are related to local utilization practices, which are beyond the scope of EMA activity. The EMA instead focuses on MA.

In contrast, the pharmacovigilance system is related to the local utilization of drugs and should be tailored to capturing the risks related to switching. In fact, no risks will be expected (they will not be found in the current literature) if there are no tools that allow their identification. This is the main finding of current research.

There are three main challenges in pursuing this goal: first, a new nomenclature should be adopted by all European countries, specific to each batch and manufacturer, allowing the individualization and identification of each biodrug. Second, registries must begin to provide information about switching - including both interchangeability and substitution. Third, there is a need for research on signals based on information collected by an updated pharmacovigilance system according to the two mentioned suggestions.

In fact, if original biologicals are identified by their brand name, which is not repeatable, the opposite happens with biosimilar drugs. As the same INN is used for different biological molecules, which come from several MA holders and manufacturing processes, registries will be unable to differentiate among the various biosimilars. Consequently, causality assessment and risk evaluation will not be possible, and no safety concerns will be identified in relation to clinical practice.

In the coming years, personalized therapy will need to be sustained by accurate data; such therapy is not compatible with the current unspecific state of the available information. Safety systems will need to cope with narrower and highly specific information and will define tailored utilization patterns for biological therapy. 
In addition, cross-border health care faces other challenges related to information-sharing across member states. Due to local regulations on switching, patients will need to cope with diverse clinical approaches in different countries. This will preclude not only the sharing of information, safety assessment, identification of determinants, but also equity. Such gaps must be overcome by the adoption of common and broader terminology, biological use patterns, and pharmacovigilance registries in Europe.

The related evolution of financing systems - currently based on population data - is being driven by risk-related data and patient-reported outcomes - personalized data - and the provision of care for rare diseases in European reference centers is mainly based on biological therapy. Biologicals are also replacing chemical therapy. Due to these topics, biologicals are definitively at the center of all stakeholders' attention.

The protection of public health requires improving the evidence base of the risks of biologicals, which can be accomplished by new tools and an updated safety regulatory framework.

\section{Acknowledgments}

The authors are grateful to Rita Henriques from the University of Lisbon for her support on the selection of papers. Language editing was performed using the Taylor \& Francis Editing Service.

\section{Funding}

The manuscript is funded by Roche Farmacêutica Química LDA and the Universidade Católica Portuguesa.

\section{Declaration of interest}

The authors are supported by Roche Farmacêutica Química LDA and the Universidade Católica Portuguesa. They have no other relevant affiliations or financial involvement with any organization or entity with a financial interest in or financial conflict with the subject matter or materials discussed in the manuscript. This includes employment, consultancies, honoraria, stock ownership or options, expert testimony, grants or patents received or pending, or royalties. Writing assistance was utilized in the production of this manuscript and funded by Roche Farmacêutica Química LDA.

\section{ORCID}

Maria da Conceição Constantino Portela (D) http://orcid.org/0000-00028802-7050

Carlos Sinogas (iD http://orcid.org/0000-0002-7161-1736

Ricardo Baptista-Leite (D) http://orcid.org/0000-0002-3503-8733

Alexandre Castro-Caldas (D) http://orcid.org/0000-0002-9148-3719

\section{References}

Papers of special note have been highlighted as either of interest $(\cdot)$ or of considerable interest (.•) to readers.

1. Tsang L. Overhauling oversight-European drug legislation. Nat Biotechnol. 2005;23(9):1050-1053.

2. DiMartino LD, Curtis LH, Williams RL, et al. Using medicare administrative data to conduct postmarketing surveillance of follow-on biologics: issues and opportunities. Food Drug Law J. 2008;63:891-900.

3. Improved guidelines will optimize efficacy and minimize adverse effects of biosimilar drugs. Drugs Ther Perspect. 2008;24:24. doi:10.2165/00042310-200824080-00008.

4. Hennessy S, Leonard CE, Platt R; Nature Publishing Group. Assessing the safety and comparative effectiveness of follow-on biologics (biosimilars) in the United States. Clin Pharmacol Ther. 2010;87(2):157-159.

5. Reinisch W, Smolen J. Biosimilar safety factors in clinical practice. Semin Arthritis Rheum. 2015;44(6):S9-S15.

6. European Parliament. Directive 2001/83/EC of the European Parliament and of the Council of 6 November 2001. [cited 2016 Jun 24]. Available from: http://ec.europa.eu/health//sites/health/files/files/eudralex/vol-1/ dir_2001_83_consol_2012/dir_2001_83_cons_2012_en.pdf.

7. Dranitsaris G, Amir E, Dorward K. Biosimilars of biological drug therapies: regulatory, clinical and commercial considerations. Drugs. 2011;71(12):1527-1536.

8. Casadevall N, Edwards IR, Felix T, et al. Pharmacovigilance and biosimilars: considerations, needs and challenges. Expert Opin Biol Ther [Internet]. 2013;13(7):1039-1047.

. To our knowledge, this is the first paper that highlights the need to differentiate safety issues related with original biologicals and biosimilars, suggesting developing the pharmacovigilance system in order to cope with challenges related to nomenclature, interchangeability, and traceability.

9. Aagaard AW, Purdy S, Philpott S. Review, approval, and marketing of biosimilars in the United States: safety and regulatory issues. Bioprocess Int. 2010;12-20.

10. European Medicines Agency. Guideline on similar biological medicinal products. Committee for Medicinal Products for Human Use; 2014 October. [cited 2017 Mar 2]. Available from http://www.ema. europa.eu/docs/en_GB/document_library/Scientific_guideline/ 2015/01/WC500180219.pdf

11. European Medicines Agency. Guideline on similar biological medicinal products containing biothecnology-derived proteins as active substance: non-clinical and clinical issues. Committee for Medicinal Products for Human Use; 2013 April. [cited 2017 Mar 2]. Available from: http://www.ema.europa.eu/docs/en_GB/document_library/ Scientific_guideline/2015/01/WC500180219.pdf

12. European Medicines Agency. Guideline on similar biological medicinal products containing biothecnology-derived proteins as active substance: quality issues. Committee for medicinal products for human use. April 2012. [cited 2017 Mar 2]. Available from: http:// www.ema.europa.eu/docs/en_GB/document_library/Scientific guideline/2014/06/WC500167838.pdf

13. Food and Drug Administration. Considerations in demonstrating interchangeability with a reference product. Guidance for industry; 2017 January. [cited 2017 Mar 2]. Available from: https://www.fda. gov/ucm/groups/fdagov-public/@fdagov-drugs-gen/documents/ document/ucm537135.pdf

14. Blackstone EA, Fuhr JP. Innovation and competition: will biosimilars succeed?. Biotechnol Healthc. 2012;9(1):24-27.

15. Bonilla JW, Beaver N. The New US biosimilar legislation, one year later. Bioprocess Int. 2011;9(5):22-30.

16. Genazzani AA, Biggio G, Caputi AP, et al. Biosimilar drugs: concerns and opportunities. BioDrugs. 2007;21(6):351-356.

- By focusing on biosimilar drugs, this paper adopts a clear and straightforward position concerning their utilization in current clinical practice and sustain potential related safety issues.

17. Heinemann L, Hompesch M. Biosimilar insulins: how similar is similar? J Diabetes Sci Technol. 2011;5(3):741-754.

18. Vulto AG, Crow SA. Risk management of biosimilars in oncology: each medicine is a work in progress. Target Oncol. 2012;7(Suppl. S1):43-49.

19. Dowlat HA. The current status of biosimilar biologics. Part 2: practical considerations in international development through European lessons learned. Regul Rapporteur. 2010;7:10.

20. Joshi SR. Biosimilar peptides: need for pharmacovigilance. J Assoc Physicians India. 2011;59(Suppl):44-47.

21. European Parliament. Directive 2010/84/EU of the European Parliament and of the Council of 15 December 2010. [cited 2016 Jun 24]. Available from: http://ec.europa.eu/health//sites/health/ files/files/eudralex/vol-1/dir_2010_84/dir_2010_84_en.pdf

22. European Parliament. Regulation (EU) No $1235 / 2010$ of the European Parliament and of the Council of 15 December 2010. [cited 2016 bJun 24]. Available from: http://ec.europa.eu/health// 
sites/health/files/files/eudralex/vol-1/reg_2010_1235/reg_2010_ 1235_en.pdf

23. European Parliament. Commission implementing regulation (EU) No 520/2012 of 19 June 2012. [cited 2016 Jun 24]. Available from: http://eur-lex.europa.eu/LexUriServ/LexUriServ.do?uri=OJ: L:2012:159:0005:0025:EN:PDF

24. European Parliament. Directive 2012/26/EU of the European Parliament and of the Council of 25 October 2012. [cited 2016 Jun 24]. Available from: http://ec.europa.eu/health//sites/health/ files/files/eudralex/vol-1/dir_2012_26/dir_2012_26_en.pdf

25. European Parliament. Commission delegated regulation (EU) No 357/2014 of 3 February 2014. [cited 2016 Jun 24]. Available from: http://eur-lex.europa.eu/legal-content/EN/TXT/?uri=CELEX\% 3A32014R0357

26. European Parliament. Commission delegated regulation (EU) 2016/ 161 of 2 October 2015. [cited 2016 Jun 24]. Available from: https:// ec.europa.eu/health/sites/health/files/files/eudralex/vol-1/reg_ 2016_161/reg_2016_161_en.pdf

27. Assembleia da República. Lei no 52/2014 de 25 de agosto; [cited 2016 Jun 24]. Available from: http://www.sg.min-saude.pt/NR/rdonlyres/ A110CE46-A607-4BD1-AB82-BE86B31314C3/39599/lei52_2014.pdf

28. Power DA, Ford D. Biological drugs and the coming of biosimilars. J Pharm Pract Res. 2008;38(2):137-139.

29. DiCicco RL. Is Europe ahead of the USA in biosimilars? J Generic Med. 2006;3(3):201-208.

30. Choy E, Allen Jacobs I. Biosimilar safety considerations in clinical practice. Semin Oncol. 2014;41(Suppl. 1):S3-S14.

- This paper expands the scope related to biosimilars safety by detailing quality, safety, and efficacy topics and their impact on several domains of pharmacovigilance system. It also provides an innovative classification related with the context of adverse events that is important to address safety related to biological therapy.

31. Khraishi M, Stead D, Lukas $M$, et al. Biosimilars: a multidisciplinary perspective. Clin Ther. 2016;38(5):1238-1249.

32. Zelenetz AD, Ahmed I, Braud EL, et al. NCCN biosimilars white paper: regulatory, scientific, and patient safety perspectives. JNCCN J Natl Compr Cancer Netw. 2011;9((Suppl):4.

33. Cutroneo PM, Isgrò V, Russo A, et al. Safety profile of biological medicines as compared with non-biologicals: an analysis of the italian spontaneous reporting system database. Drug Saf. 2014;37 (11):961-970.

34. Dowlat HA. Perceptions and realities of clinical safety of biosimilars EU and US perspectives: part 1. Regul Rapporteur. 2012;9(4):20-25.

35. Li EC, Abbas R, Jacobs IA, et al. Considerations in the early development of biosimilar products. Drug Discov Today. 2015;20(S2):1-9.

36. Ruiz S, Calvo G; Nature Publishing Group. Similar biological medicinal products: lessons learned and challenges ahead. J Generic Med Bus J Generic Med Sect. 2011;8(1):4-13.

37. Dammacco F, Abbracchio MP, Gesualdo L, et al. Biosimilars and safety issues. Leuk Lymphoma. 2009;50(4):656-658.

38. Combe C, Tredree RL, Schellekens H. Biosimilar epoetins: an analysis based on recently implemented European medicines evaluation agency guidelines on comparability of biopharmaceutical proteins. Pharmacotherapy. 2005;25(7):954-962.

39. Locatelli F, Roger S. Comparative testing and pharmacovigilance of biosimilars. Nephrol Dial Transplant. 2006;21(Suppl. 5):v13-6.

40. Dowlat HA. Perceptions and realities of clinical safety of biosimilars EU and US perspectives: part 2. Regul Rapporteur. 2012;9(5):16-19.

41. Yamaguchi T, Arato T. Quality, safety and efficacy of follow-on biologics in Japan. Biologicals. 2011;39(5):328-332.

42. Macdonald JC, Hartman H, Jacobs IA. Regulatory considerations in oncologic biosimilar drug development. MAbs. 2015;7(4):653-661.

- This paper allows a critical perspective about naming and switching both in Europe and the United States.

43. Young KE, Rémuzat $C$, Urbinati $D$, et al. Boosting biosimilars uptake in European countries. ISPOR 17th Annual European Congress, Amsterdam, The Netherlands, 8-12 Nov, 2014. PHP23.
44. Drozd M, Szkultecka-Dębek M, Baran-Lewandowska I. Biosimilar drugs - automatic substitution regulations review. Polish ISPOR chapter's Therapeutic Programs and Pharmaceutical Care (TPPC) task force report. J Heal Policy Outcomes Res. 2014;1:52-57.

45. Kurki $P$, Aets $L$, Wolff-Holz E, et al. Interchangeability of biosimilars: a European perspective. Bio Drugs. 2017;31:83-91.

46. Danish Medicines Agency. Biological and biosimilar medicinal products. [cited 2016 Jun 24]. Available from: https://laegemiddelstyrel sen.dk/en/sideeffects/biological-and-biosimilar-medicinal-products

47. Garcia A, Hernandez G, Avendaño S. Regulación de los medicamentos genéricos : evidencias y mitos. Inf Ter Sist Nac Salud. 2010;34(3):71-82.

48. Sociedade Espanhola de Farmacologia Clínica. Posicionamento sobre identificación, intercambiabilidad y sustitución de medicamentos biosimilares. 2015. [cited 2016 Jun 24]. Availabvle from: http:// www.actasanitaria.com/wp-content/uploads/2015/09/sefc.pdf

49. Real Decreto 1718/2010 de 17 de dezembro. [cited 2016 Jun 24]. Available from: http://www.seg-social.es/Internet_1/Normativa/index. $\mathrm{htm}$ ?dDocName $=143907 \& C 1=1001 \& \mathrm{C} 2=2010 \& C 3=3027 \& \mathrm{C} 4=4002$

50. FIMEA. Interchangeability of biosimilars - Position of finnish medicines agency Fimea. 2015. [cited 2016 Jul 30]. Availabe from: https://www.fimea.fi/documents/542809/838272/29197_ Biosimilaarien_vaihtokelpoisuus_EN.pdf.

51. Pasina L, Casadei G, Nobili A. Biological agentes and biosimilars: essentialinformation for the internist. Eur J Intern Med. 2016;33:28-35.

52. Declerck PJ. Biotherapeutics in the era of biosimilars. What really matters is patient safety. Drug Saf. 2007;30(12):1087-1092.

- This paper addresses the main perspectives and risks related with the nomenclature of biologicals, sustaining the need to adopt a different naming for biologicals.

53. CBG. Medicines Evaluation board. MEB stance on prescribing "biosimilars"; [cited 2016 Jun 24]. Availabe from: http://english.cbgmeb.nl/latest/news/2015/03/31/meb-stance-on-prescribing-\%E2\% 80\%9Cbiosimilars\%E2\%80\%9D

54. CBG. Medicines Evaluation board. Clarification of stance on biological and biossimilar medicines; [cited 2016 Jun 24]. Available from: http://english.cbg-meb.nl/latest/news/2015/08/17/clarification-ofstance-on-biological-and-biosimilar-medicines

55. Direção Geral da Saúde. Norma da Direção Geral de Saúde. Centro Prescritor de Agentes Biológicos; 2014. [cited 2016 Jun 24]. Available from: https://www.dgs.pt/ms/8/pagina.aspx?js=0\&codi goms $=5521 \&$ codigono $=02080254$ AAAAAAAAAAAAAAAA

56. Infarmed. Orientações da Comissão Nacional de Farmácia e Terapêutica. Biossimilares. 2016. [cited 2016 Jun 24]. Available from: http://www.infarmed.pt/documents/15786/1816213/1 Orienta\%C3\%A7\%C3\%B5es_CNFT_Completa_Final.pdf/bd4475fc147b-4254-a546-03b8cd63efff

57. Thijs J, Giezen TJ, Mantel-Teeuwisse AK, et al. Safety-related regulatory actions for biologicals approved in the United States and the European Union. JAMA. 2008;300(16):1887-1896.

58. World Health Organization. Biological Qualifier. An INN Proposal. Programme on International Nonproprietary Names (INN) INN Working Doc. 14.342 Revised draft July 2014. [cited 2016 Jun 24]. Available from: http://www.who.int/medicines/services/inn/bq innproposal201407.pdf

59. Castle GH, Kelly B. Global harmonization is not all that global: divergenteapproaches in drug safety. Food \& Drug L.J. 2008;63:601-622.

60. Barnes HJ, Ragnarsson G, Alván G. Quality and safety considerations for recombinant biological medicines: a regulatory perspective. Int J Risk Saf Med. 2009;21(1-2):13-22.

61. Chamberlain $P$, Mire-Sluis A. Constructing an immunogenicity risk assessment for follow-on biologics. J Generic Med. 2005;2(2):133-144.

62. Ferro $H$, Donato $H$, Valtuille $R$, et al. Worldwile pharmacovigilance of a biossimilar product containing Epoietin. Drug Saf. 2008;31(10):885-960.

63. Zemkova M, Jebavy L, Kotlarova J, et al. The spectrum and types of adverse side effects to biological immune modulators: a proposal for new classification. Folia Biol (Praha). 2007;53(4):146-155.

64. Berthet-Maillols E. Biosimilars: the reasons to be confident. STP Pharma Prat. 2008;18(6):541-567. 